nothing to do with it. Briefly, the essence of the scheme is to secure an effective partnership between the State and the local authority for furthering agricultural education. Each scheme has to be considered as a whole and estimates planned before it is put into operation; then the cost is to be divided between taxpayer and ratepayer on an approved scale.

The effect of the partnership will be more than financial; it is by no means intended that the State shall be the sleeping and paying partner. The agricultural resources of the country have got to be developed to the fullest extent, and this is no time for allowing any backward county council to block the way.

As might have been expected, the war has had a serious effect on the agricultural colleges and research institutes. The best of their young men volunteered at once for military service. Some of the colleges were practically emptied, and the research institutes lost their most vigorous and enterprising workers, some, alas! never to return. But, to the credit of the Board, the principle that education and research must be kept going has so far been successfully maintained, and although the grants are rightly reduced automatically as members of the staff enlist, there is no evidence from the report that any of the institutes have suffered financially. In return, it is satisfactory that the Board is able to record that the research institutes and colleges have rendered valuable help in dealing with the special problems arising out of the war. It never was more necessary than now that farmers should have the best expert advice available, and it is gratifying to know that all concerned are doing their utmost to help in the emergency. Research institutes subsidised by Government are new things to the ordinary taxpayer, and a great responsibility devolves on them to justify themselves in the present emergency. If science can help agriculture, surely this is the time for doing so.

\section{SIR HENRY ROSCOE, F.R.S.}

B $Y$ the death of the Rt. Hon. Sir Henry Enfield Roscoe, through heart-failure, on December 18, at his residence, Woodcote Lodge, West Horsley, we lose one more of that rapidly dwindling body of men of whom Huxley may be said to be the type and leader, who spent their energies, after the passing of the Education Act of 1870 , and largely in consequence of it, in attempting to rouse this country to a sense of the national importance of secondary and technical education. Except for occasional trouble with gout, and the slight infirmities of advanced age, he was in his usual state of good health and happy serenity of mind up to within the very hour of his seizure. It was such a passing as he would himself have desired; a swift and painless ending to a long, strenuous, and honourable career.

As he tells us in his "Life and Experiences," an autobiographical record which he published in
1906, with the characteristic motto on its titlepage, from Carlyle's "Sartor Resartus,"

What is the use of health,

Work therewith?

he first saw the light at ro Powis Place, off Great Ormond Street, London, on January 7, 1833 . His father, Henry Roscoe, was a barrister, and became Judge of the Court of Passage in Liverpool; his "Digest" was for many years a standard work of reference. Roscoe's grandfather, William Roscoe, was a still more remarkable man, who from very humble beginnings raised himself to a position of affluence, and of considerable influence in his native town. $\mathrm{He}$ represented Liverpool for a session in the Parliament of 1806 as an advanced Liberal, but in 1816 lost his fortune by the failure of a bank in which he was a partner. He left his mark on our literature by his "Lives of Lorenzo di Medici and Leo X." He also made occasional contributions on botanical subjects to the Linnean Society.

Roscoe's mother was a Miss Fletcher, the daughter of a Liverpool merchant, who also lost his money by the failure of a bank. She was a highly capable woman, of great force of character, and lived to a green old age. She had considerable artistic gifts, and on the death of her husband after five years of married life, when she was left with very straitened means, she gave lessons in painting. She had, too, literary ability, and when well advanced in years published a life of "Vittoria Colonna," with admirable translations of the sonnets. Roscoe's forbears on both sides were of Presbyterian or Unitarian stock, his great-grandfather on the mother's side being Dr. Enfield, a colleague of Priestley in the Warrington Academy, and the author of the once wellknown "Enfield's Speaker."

After a few years at a preparatory school Roscoe was sent to the High School of the Liverpool Institute, where he had little Latin and less Greek, but, what was remarkable in those days, a certain modicum of science. His teacher of chemistry was Balmain, the discoverer of "luminous paint" and of boron nitride, a genial and capable instructor, from whom he seems to have acquired his taste for the science. At all events he now started experimenting on his own account, and began his career as a lecturer by giving demonstrations to his sister, his cousins, and, no doubt, also his aunts, at a charge of one halfpenny each person, to defray the cost of the chemicals-the summit of his ambition at that time being, as he said, to "burn phosphorus in oxygen on a large scale before an admiring audience."

The attitude of the older universities towards Dissenters at this period caused Roscoe to be sent to University College, London, which he entered in $\mathrm{r} 848$ with a view to preparing for a degree of the University of London. Here he came under the influence of Graham, at that time professor of chemistry, and afterwards of Williamson, who succeeded him. He took his degree in 1853 , and decided to follow chemistry as a profession.

NO. 2408, vOL. 96] 
He had acted for a short time as Williamson's private assistant, and had helped him in the experimental illustration of his lectures. Williamson was then in the heyday of his activity. It was the beginning of a new epoch, which was destined to have a profound influence on the development of chemistry, theoretical and practical-a movement in which Williamson was a pioneer, and Gerhardt, Laurent, Hofmann, and Kekulé were active agents. It is perhaps idle to speculate what would have been the course of Roscoe's career had he remained at University College in association with Williamson. In mental habitudes the men had not much in common. Roscoe at no time had any active sympathy with the philosophical side of chemistry, and chemical speculation had few attractions for him. His mind was essentially practical, and hence the achievements of determinative chemistry were what he chiefly valued. He probably, therefore, did wisely in going to Heidelberg, for he found in Bunsen a type of mind like his own, and a worker with whom he was in complete accord, and their acquaintance soon ripened into a friendship which ended only with Bunsen's death. How completely the two were in sympathy may be seen in Roscoe's admirable memorial lecture on Bunsen which he gave to the Chemical Society, and it is reflected no less clearly in the pages of his autobiography.

Roscoe's life in Heidelberg and his intimate association with Bunsen brought him into close contact with all that was worthiest in German university life, and he contracted firm friendships with many of the most eminent men of that period - the two Roses, Magnus, Kirchhoff, Helmholtz, Kopp, Koenigsberger, Quincke, and others. He always looked back upon this time as one of the happiest memories of his life. He had to the last a very tender regard for what is best in the German character as it was revealed to him in the many friends he learned to know and to love at this period. He viewed with increasing anxiety and regret the growth of the strained relations between the governing powers in Germany and this country, and his last literary efforts were directed, so far as it was possible to him, to mitigate them. "It would be an outrage to civilisation," he wrote, "if two countries so closely allied in blood and intellectual development should ever come to blows." And when the rupture did come it clouded the few remaining months of his life.

Roscoe's first and only professorship was at Owens College, Manchester, to which he was elected in 1857 as successor to the late Sir Edward Frankland. At that time it was the day of small things with the College. As an institution it was looked at somewhat askance by reason of the terms of its founder's intentions in regard to religious tests and instruction. It was inadequately endowed, and poorly housed in a building of which the only claim to distinction was that it was formerly the residence of Richard Cobden. Fortunately it was staffed by an excepNo. 2408 , VOL. 96] tionally able body of young and enthusiastic teachers, limited in number but united in their determination to keep the lamp of learning alight in the squalid and benighted regions of Deansgate. This is not the place, even if space permitted, to dwell upon the progress and development of Owens College, or to show how it grew eventually into the University of Manchester. During the thirty years of his connection with the institution Roscoe took a leading part in stimulating and fostering this development, and before he severed his connection with it as an active teacher he had the gratification of seeing it attain to full university honours. To this success his efforts in erecting a school of chemistry in no small degree contributed. He made its chemical laboratories famous throughout the world, and at one time or another students from nearly every civilised country were to be found working within its walls. This result was due not so much to Roscoe's influence as a leader in chemical inquiry; students were not attracted as in a German university, solely by the fame of the professor's researches; they came, in the first instance, on account of the thoroughness and comprehensiveness of the instruction; they remained because of the stimulating effect of the atmosphere of research into which they were eventually led.

The scheme of instruction which Roscoe introduced was essentially that at Heidelberg, and he followed Bunsen's methods and example. His success as a teacher was largely owing to his energy, his power of organisation and business aptitudes, his judgment of men and capacity for getting the best out of them. He was not what could be termed a brilliant lecturer; he had nothing, for instance, of the fire and enthusiasm of Hofmann; but his language was simple, direct, and to the point, with not the least pretension to rhetorical effect, in all of which, as in other respects, he resembled Bunsen. Like Bunsen, too, he took considerable pains in the experimental illustration of his teaching; in this he was assisted by a skilful and ingenious collaborator, Heywood, well known to Owens College men of a generation or so ago. How affectionately Roscoe was regarded by his students, and how gratefully they recalled their obligations to him, may be seen from the terms of the address, signed by three hundred of them, which they presented to him on the occasion of his jubilee as a doctor of philosophy of the University of Heidelberg. It may be seen, too, in their gift of his portrait by Herkomer to the late Lady Roscoe on his retirement from his professorship, and in the presentation of his bust by Mr. Drury to the Chemical Society on the attainment of his eightieth birthday.

The volume of Roscoe's original work in chemical inquiry when compared with the output of many of his contemporaries, especially on the Continent, cannot be considered large. His most important investigations were his photochemical researches, partly done in concert with Bunsen, and his work on the chemistry of vanadium. His first memoir on the latter subject was made the 
Bakerian lecture of 1868 , and the value of both was further recognised by the Royal Society by the subsequent award to him of a Royal Medal.

Other important work which has long since taken its due place in the literature of the science is his observations on the constitution of aqueous solutions of acids and his investigation on perchloric acid and its compounds.

Roscoe did a notable service to science by his action in making Bunsen and Kirchhoff's work on spectroscopy generally known in this country, and during the early 'sixties there were few of our larger towns in which he did not demonstrate by means of popular lectures the astonishingly interesting results of the then novel form of chemical analysis. His first lectures on the subject in London were republished in collected form, suitably illustrated, and the book had a considerable success and passed through several editions. $\mathrm{He}$ made, in addition, a number of original spectroscopic inquiries, the results of which appear in the publications of the Royal Society.

But the work by which he will continue to be known is the service he rendered to teaching by his many manuals of instruction, some of which were highly popular, ran through many editions, and were translated into a variety of languages. Of these the most important is the large treatise in which he co-operated with his former assistant and friend, Carl Schorlemmer, the first professor of organic chemistry in this country, a man of great erudition, and an able and wellinformed chemist. No combination of workers could be more happily selected, for each, in a sense, was complementary to the other. Schorlemmer was the bibliographer, with quite a remarkable knowledge of chemical literature and an extraordinarily retentive and accurate memory, whilst Roscoe's gift of exposition and faculty of clear and simple statement and of systematic arrangement enabled all the accumulated wealth of facts to be set forth in an eminently attractive and readable form.

This appreciation is concerned more particularly with Roscoe as a teacher engaged in the pursuit of experimental inquiry, with which aspects of his career the writer may claim to have some right to speak from personal knowledge. It must be left to others to deal with his many other activities during the later years of his life, such as his political life, his work in regard to technical education, and in connection with the still unsolved problem of the true function of a great metropolitan university, and the important services he rendered to preventive medicine in his association with the Lister Institute.

T. E. THORPE.

\section{NOTES.}

Sir Archibald Grikie, O.M., K.C.B., F.R.S., will reach his eightieth birthday next Tuesday, December 28. He is in excellent health, and still busy with his pen.

WE announce with much regret the death on Decem-

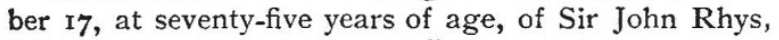
NO. 2408, VOL. 96] principal of Jesus College, Oxford, and professor of Celtic in the University. In addition to his other titles to distinction, Sir John Rhys was well known for his work in archæology and anthropology. He was president of the Anthropological Section of the British Association in 1900.

LoRd Alverstone, late Lord Chief Justice of England, whose death occurred on December 15, was a fellow of the Royal Society, having been elected in 1902 under a statutory provision, formerly in operation, which allowed of the election of Privy Councillors. He was a familiar figure at the society's annual soirees, and from time to time attended and spoke at the presidential anniversary banquets. Lord Alverstone had a long and traditional connection with the Royal Society of Arts, the son in this respect continuing the highly useful services rendered by his father, $\mathrm{Mr}$. Thomas Webster, Q.C. Elected on the council in 1883, he was chairman of that body from 1890 to I894, remaining afterwards an ordinary member of council for a long period of years. On King George's accession to the throne in I910, the presidency of the society became, thereby, vacant, and the late Lord Chief Justice accepted the post. He resigned in IgII in order to make way for his Royal Highness the Duke of Connaught. It may be recalled that Lord Alverstone opened the proceedings of the "Law, Political Economy, and Legislation Affecting Chemical Industry" Section of the International Congress of Applied Chemistry, held at South Kensington in 1909, giving a thoughtful address on the right method of legislating upon and dealing with scientific technical knowledge.

THE letters in the Times during the last few days from Mr. C. H. L. Alder, Sir William Ramsay, and Mr. J. A. Goudge again direct attention to a remarkable state of affairs. As recently pointed out in NATURE, Germany is necessarily suffering from a serious shortage of fats, and consequently of glycerine, which is obtainable from no other source. Notwithstanding our supposed blockade, Germany is making up for this shortage by the import, through neutral countries, of fats and oil-containing seeds. Though primarily produced abroad, the fatty materials to a large extent pass through British hands and British ports. In the correspondence referred to, disturbing statistics are given concerning linseed, which is one fatty material out of many. Sir William Ramsay shows by a simple calculation that from linseed oil alone our Government has furnished the enemy with no fewer than 18,000 tons of gun ammunition. Actually the position is much worse, and the additional complication is now arising that, owing in part to the general dislocation of transport, there is more than a possibility of a future shortage of fatty materials, and consequently of glycerine, in this country. The price of fats here is rising in an alarming manner, though since their cost is still small compared with that ruling in Germany, the financial temptations to export to neutral countries bordering on Germany remain immense. It is difficult to understand whether the present policy of the Government is due to want of knowledge or to reasons of high 